\title{
Sobre o filósofo como educador em Kant e Nietzsche
}

O swaldo Giacoia Junior

IFCH/ Unicamp

resumo Este trabalho pretende comparar a concepção de formação filosófica em Kant e Nietzsche. A metáfora do filósofo como legislador constitui a peça central na análise hermenêutica de ambos os pensadores.

palavras-chave Filosofia - Filósofo - Legislador - Kant - Nietzsche - Platão

0 presente trabalho pretende sugerir uma aproximação algo inusitada entre as concepções de formação filosófica em $\mathrm{N}$ ietzsche e K ant. Invertendo a cronologia, tomo como ponto de partida uma tentativa de interpretação de alguns textos centrais de $\mathrm{N}$ ietzsche a respeito do tema textos que não se limitam a uma única fase do pensamento desse autor -, para depois contrastá-los e procurar fazê-los convergir com aspectos essenciais da posição de K ant.

Q uase um século depois da publicação da primeira edição da C rítica da R az ão Pura, quando as mentes mais sensíveis já podiam preconizar as conseqüências e desdobramentos culturais da configuração da sociedade civil burguesa emergente da revolução industrial, Friedrich $\mathrm{N}$ ietzsche retomava, em nova chave, o tema clássico da vocação pedagógica e libertária da filosofia.

0 ponto de partida de $\mathrm{N}$ ietzsche consiste numa crítica fulminante da preguiça, da pusilanimidade, da vergonhosa busca de acomodação e anonimato que constituem o traço distintivo do homem moderno, até na mais rarefeita atmosfera do espiritual: sua obsessão em ocultar-se sob opiniões e costumes alheios.

R ecebido em janeiro de 2005. A ceito em julho de 2005.

doispontos, Curitiba, São Carlos, vol. 2, n. 2, p.77-96, outubro, 2005 
"N o fundo, todo homem sabe muito bem que ele, como um unicum, está no mundo apenas uma vez, e que nenhum tão curioso acaso misturará pela segunda vez numa unidade, como ele é, uma tão admirável e colorida variedade: ele o sabe, mas ele o oculta, como uma consciência malvada - por que? Por temor do vizinho, que exige a convenção e se oculta a si mesmo com ela. M as o que é isso que coage o particular a temer 0 vizinho, a pensar e a agir conforme 0 rebanho e não estar alegre consigo mesmo? Pudor, talvez, em alguns e poucos. Para a maioria, é comodidade, inércia, em resumo, aquele pendor para a preguiça." (N IET ZSC HE, 1980a. p. 337).

É justamente por causa dessa preguiça e covardia que o homem moderno desperta o desprezo de todo grande pensador; pois, justamente por causa desse ocultamento no anonimato tranqüilizador da opinião pública, todos figuramos como "mercadorias de fábrica, como indiferentes, indignos do trato e do ensinamento. 0 homem que não quer pertencer à massa, precisa apenas cessar de estar confortado consigo mesmo; que ele siga sua consciência moral, que o conclama: 'seja você mesmo! Você não é nada daquilo que você agora faz, pensa e deseja". (N IETZSCHE, 1980a. p. 338).

Portanto, quem quer se desgarrar da massa uniforme, que aspira por si mesmo e pretende viver segundo sua própria medida e legislação, este tem que se responsabilizar pela direção da própria existência, não permitindo que ela se iguale a um penoso acaso desprovido de pensamento. Essa tentativa de se soltar da opressiva artificialidade convencional e da acomodação burguesa significa, para $\mathrm{N}$ ietzsche, emancipação, e constitui a mais genuína aspiração da alma jovem.

Esta, em seu ímpeto juvenil, clama para si mesma:

"N ada disso és tu mesmo. $N$ inguém pode construir para ti a ponte sobre a qual tu precisamente tens que passar sobre o rio da vida, ninguém além de ti mesmo. Decerto que há inumeráveis atalhos e pontes e semi- deuses que querem te carregar através do rio; mas apenas ao preço de ti mesmo; tu te darias em penhor e te perderias. Há no mundo um único caminho que ninguém pode trilhar, além de ti: para onde conduz ele? $\mathrm{N}$ ão perguntes, prossegue. $\mathrm{Q}$ uem foi aquele que enunciou o seguinte princípio: 'um homem jamais se eleva mais alto 
do que quando não sabe para onde seu caminho ainda o pode conduzir'" (N IETZSCHE, 1980a, p. 340).

0 problema consiste, já podemos percebê-lo, em saber como encontrarnos a nós mesmos, depois de nos termos perdido na selva das opiniões comuns, dos costumes, das convenções, da tradição e do politicamente correto. Como nos elevarmos até aquela al tura onde podemos vislumbrar algum indício de nós mesmos? Como dar cumprimento àquele sublime preceito pedagógico inscrito no oráculo de Delfos, que Sócrates transformou na divisa suprema da filosofia?

A meu ver, de acordo com $\mathrm{N}$ ietzsche, não pelo caminho da interioridade proposto por Sócrates, pois como poderíamos nos conhecer interiormente se, antes disso, temos que realizar a tarefa sobre-humana de descobrir uma (nossa) identidade, se antes de poder divisar um ponto onde estaríamos fixados, temos que nos desgarrar e nos perder daquilo que julgávamos erroneamente ser nosso 'Eu', se temos de retraçar, a posteriori, 0 desenho de um estilo que imprime a unidade de um caráter à diáspora de nossa existência?

Para $\mathrm{N}$ ietzsche, não despencamos em queda livre e direta para a caverna que abriga o tesouro de nossa ipseidade, nem é arrancando violentamente nossas peles que descobriremos o recôndito âmago de nosso si próprio. A o contrário, tudo aquilo que nos cerca e acompanha, ao longo de nossa existência, presta testemunho indireto de nossa essência: amizades e inimizades, amores e aversões, memória e esquecimentos, palavra e silêncio, tempos e lugares, nosso olhar e nosso aperto de mão, nossos livros e escritos, os traços de nosso punho e as linhas de nosso rosto.

Q ue a jovem alma olhe para trás, sobre sua vida, sugere $\mathrm{N}$ ietzsche, e que pergunte:

"o que, até agora, verdadeiramente amaste, o que atraiu tua alma, o que a dominou e ao mesmo tempo a felicitou? Coloca diante de ti a série desses venerados objetos, e talvez eles te proporcionem, por sua essência e sucessão, uma lei, uma lei fundamental de teu próprio ti mesmo. Compara esses objetos, vê como um complementa, alarga, sobrepuja, transfigura o outro, como eles formam uma escada, sobre a qual tu até agora te elevaste para ti mesmo; pois tua verdadeira essência 
não jaz profundamente oculta em ti, mas imensamente acima de ti, ou ao menos sobre aquilo que costumeiramente tomas como o teu eu." (N IET ZSC HE, 1980a, p. 340).

Temos nesse trecho uma das indicações mais preciosas para a solução da questão que nos ocupa: aquilo que dá testemunho de nossa verdadeira identidade não está soterrado na profundeza de nosso ser - ou, se estiver, ao menos não é acessível por esse caminho. $\mathrm{N}$ ão é para dentro, para baixo e para 0 abismo que devemos nos dirigir, mas para o exterior - para as séries de nossos encontros, nossas afecções e experiências -, sobretudo muito acima daquilo que ingenuamente tomamos por nosso 'Eu'. N osso percurso de formação é pontuado pela presença constante do outro, desenhando, portanto, uma linha de fuga em relação a um pseudo centro identitário, um movimento de afastamento, que possibilita a reaquisição, por um retorno reflexivo a si 1 .

Há que se observar, entretanto, que essa busca de si, que de início se dirige à série de nossos objetos venerados - sem descuidar da significação, pelo negativo, daquilo de que fugimos e odiamos - constitui um dos degraus do caminho ascendente em que nos elevamos a nós mesmos. 0 utro degrau, de importância fundamental, é formado precisamente por aqueles que tomamos como educadores:

"Teus verdadeiros educadores e formadores te revelam o que é 0 verdadeiro sentido originário e a matéria fundamental de tua essência, algo inteiramente não ensinável, não modelável, em todo caso dificilmente acessível, atado, entravado: teus educadores conseguem não ser mais que teus libertadores. E esse é o segredo de toda educação: ela não confere próteses artificiais, narizes de cera, olhos oculizados - pelo contrário: 0 que consegue proporcionar tais dons é antes imitação de educação. Esta, porém, é libertação, remoção de toda erva daninha, entulho, vermes, que querem atingir a delicada semente da planta, jorro de luz e calor, amoroso murmúrio de chuva noturna; ela é imitação e adoração da natureza, onde esta é maternal e misericordiosamente disposta; é aperfeiçoamento da natureza, quando previne e volta para o bem os cruéis e impiedosos acessos, quando estende um véu sobre as exteriorizações de sua disposição madrasta e de sua triste incompreensão" (N IET ZSC HE, 1980a. p. 340). 
Gostaria que me fosse permitido aqui chamar a atenção para certas figuras persistentes na filosofia de $\mathrm{N}$ ietzsche, que têm sido objeto de muita controvérsia e incompreensão: ao apresentar o 'verdadeiro sentido originário e a matéria fundamental' de nosso ser - nossa 'essência', por assim dizer -, como um núcleo entravado, um caroço não passível de ensinamento e aprendizado, de formação e configuração <unerziehbar, unbildbar>, $N$ ietzsche dá a impressão de tratá-lo como nódulo tosco e embotado.

Essa impressão é igualmente suscitada por um texto escrito cerca de 15 anos depois de Schopenhauer como E ducador, em que $\mathrm{N}$ ietzsche retoma esse topus, modifica e radicaliza ainda mais as metáforas e alegorias:

"O aprendizado nos transforma, faz o que faz a nutrição, que não apenas 'conserva' - como sabe o fisiólogo. Porém, no fundo de nós, totalmente 'lá embaixo', há, em verdade, algo que não se deixa instruir, um granito de fatum espiritual, de decisão e resposta predeterminadas para questões predeterminadas e seletas. Em todo problema cardeal fala um imutável 'isso sou eu': sobre homem e mulher, por exemplo, nenhum pensador pode mudar seu aprendizado, mas somente aprender até 0 fim - descobrir até o fim aquilo que, sobre 0 assunto, para ele 'está estabelecido'." (N IET ZSC HE, 1980b. p. 170).

Entretanto, seria oportuno contrastar essa aparente rudeza das imagens iniciais com uma ambiência delicada, frágil e amorosa, que com ela convive no mesmo texto. $\mathrm{N}$ essa segunda ambiência, predominam as metáforas botânicas do cultivo e jardinagem, bem como as alegorias do cuidado materno: aqui se trata de extirpar ervas daninhas e remover detritos e vermes para preservar as indefesas e delicadas primícias ainda em botão; aqui se fala em feixe de luz solar e tepidez, terno murmurejar de chuva noturna, numa clara alusão ao desvelo maternal; por fim, comparece a imagem áurea da preservação, aquela retificação que consiste em prevenir e reverter a fúria desencadeada dos elementos, de transfiguração da natureza, cobrindo de véus de beleza seus cruéis e desapiedados assomos. Cuidar significa aqui o mesmo que educar - pois o segredo de toda verdadeira educação é libertação, no sentido de arejamento, iluminação, promoção, abertura de espaços e horizontes, desabrochamento, emancipação. 


\section{2}

Se retornarmos ao aforismo 231 de Para A lém de Bem e $M$ al sob o influxo dessa impressão anacrônica (pois colhida num texto de 1873), descobriremos que também naquele livro mais tardio está presente uma dialética das imagens antagônicas. C om efeito, logo depois da referência à ineficácia do aprendizado face a um fatum imutável, que predetermina respostas para problemas cardinais, $\mathrm{N}$ ietzsche acrescenta: “ $\mathrm{D}$ e tempos em tempos, encontramos certas soluções de problemas que justamente nos produzem uma crença forte; talvez as denominemos daí para diante "convicções'" (NIETZSCHE, 1980b, p. 170). Tudo se passa como se nossas mais firmes e bem estabelecidas convicções fossem algo mais do que uma crença e opinião; como se fossem a direta e inequívoca exteriorização daquele granítico 'isso sou eu', o rosto definitivo por detrás de nossas máscaras. Todavia, descobrimos ainda, com o tempo, que mesmo nossas certezas aparentemente autênticas e definitivas são apenas outros tantos disfarces, signos que remetem ainda a outra instância.

" $M$ ais tarde - vemos nelas tão-somente pistas para 0

autoconhecimento, indicadores de caminho para o problema que somos

-, mais concretamente, para a grande estupidez que nós somos, para

nosso fatum espiritual, nosso resistente ao aprendiz ado, totalmente 'lá

embaixo'" (N IET ZSCHE, 1980b, p. 170).

0 fatum que resiste a todo aprendizado - a rocha de certeza a remover enfim toda dúvida - se revela, pois, no decurso do tempo e das experiências, como 'o problema que somos', como a 'estupidez que somos', cujo remoto paradeiro nos é indicado pelas pegadas de nossas conviç̧ões. Também aqui - como no caso da delicada semente - o fatum é o que não se deixa apreender, a inexorável contingência volátil que se furta a toda grosseira e impertinente tentativa de apreensão.

$R$ etornemos, depois disso, ao problema que nos ocupava desde 0 início, ou seja à questão da formação, pois agora podemos formular explicitamente, em toda sua envergadura, 0 intrincado paradoxo, que até então estivera apenas sugerido: aqueles que nos educam e que nos formam, são os que constituem os nossos mais fecundos encontros, pois que, por sua natureza e pela série que inscrevem na trajetória de nossa existência, revelam-nos o autêntico sentido originário e a matéria fundamental de nossa "essência". C ontudo, não podem fazê-lo senão conju- 
rando justamente o contrário deles mesmos, a saber: aquele algo inteira mente não passível de ensino, aprendizado, formação, modelagem como o "estúpido problema de nosso ser", que não se deixa apreender senão pelo indireto e diáfano reflexo projetado na superfície especular de nossos educadores.

Por essa razão, do ponto de vista de $\mathrm{N}$ ietzsche, aquele terrível esforço e penosa obrigação de instruir-nos para a autenticidade e como que formarmo-nos a nós próprios, podem ser, em certa medida, aliviados pelo destino: para tanto, seria necessário que, no justo tempo, encontrássemos um verdadeiro filósofo, a quem pudéssemos obedecer sem ulteriores reservas e condições, pois nele poderíamos confiar ainda mais que em nós mesmos.

Vale aqui, penso poder afirmar, a máxima evangélica: lá onde está depositado teu maior tesouro, ali está também teu coração. E é precisamente nesse ponto que se cruzam, para não mais se separar, filosofia, ensino, educação e formação - pois filosofia é o mais sublime objeto de veneração; como amor da sabedoria, ela é a figura suprema do amor. A despeito de todo seu arrebatado e incendiário ímpeto iconoclasta, também para $\mathrm{N}$ ietzsche a "mais veraz de todas as ciências" é "a honrada deusa nua Filosofia" (N IET ZSCHE, 1980c, p. 282).

Encarnação da filosofia, o filósofo pode ser o signo concreto desse amor ideal pelo mais remoto e sublimado: pela casta nudez da verdade. Por essa razão, o verdadeiro filósofo é também o verdadeiro educador, pois ele não proporciona ao discípulo réplicas sem vida de seus membros naturais, próteses artificiosas, nem subterfúgios consoladores. A o filósofo, como verdadeiro educador, cumpre ser o guia e o promotor daquele que se encontra a caminho para sua mais genuína vocação, para o seu amor mais elevado - em outras palavras, para a justa e completa maturação e florescimento daquele indefeso cerne entrevado, informe, agrilhoado e soterrado de entulho, que aspira por desabrochar, por ser libertado e trazido à luz da figuração.

Entretanto, o que significa educar, instruir, formar, num tempo como 0 nosso, que exige a especialidade e que pressiona por nos tranformar em "indistintas mercadorias de fábrica", indignas do trato e do aprendizado? M esmo nossa época das especializações atomizadas oscila entre duas máximas fundamentais da educação: 
"U ma delas exige que o educador deva reconhecer logo a fortaleza própria de seu pupilo, e então direcionar precisamente para lá todas as forças e seivas e todo brilho de sol, para auxiliar aquela virtude para uma correta maturação e fecundidade. A outra máxima quer, ao contrário disso, que o educador atraia a si todas as forças existentes, trate delas e as traga para um relacionamento harmonioso" (N IET ZSCHE, 1980a p.342).

Trata-se, portanto, de exigências operando em sentido contrário: uma delas prescreve a drenagem de todas as energias do corpo e do espírito para a intensificação máxima de um talento singular; a outra determina justamente o cultivo para a totalidade harmônica das forças, o jogo conjunto das múltiplas vozes em uma mesma natureza. C omo, porém, conciliar as duas coisas? Como obter aquele concerto polifônico de vozes concorrentes quando a pujança de um talento singular se mostra especialmente vigorosa? Seria necessário sufocá-la pela disciplina opressiva de uma inclinação contrária, artificialmente implantada? 0 u uma harmonia do múltiplo só seria possível onde a pluralidade dos dons não vai além de uma indigente mediocridade?

Para N ietzsche, entretanto, não se trata aqui de contradição insolúvel, pois justamente em criaturas em que fortes pendores e talentos imperiosos, múltiplos e concorrentes, aspiram a um ponto nodal e a uma força de raiz, com dominador e coercivo poder superior para instituir entre eles um harmônico sistema de movimentos, é que podem ocorrer as mais perfeitas configurações de unidade do diverso, os mais afortunados e felizes pactos de concórdia no conflito de faculdades. É do máximo tensionamento conjunto das cordas que se obtêm as tonalidades sonoras mais refinadas, assim como é 0 arco maximamente retesado entre os dois pólos extremos que permite ambicionar e lançar a flecha para os alvos mais difíceis e remotos.

“E assim talvez as duas máximas não sejam de modo algum contrárias?

Talvez uma diga apenas que o homem deve ter um centro, a outra que ele deve ter uma periferia. Aquele filósofo que sonho para mim certamente descobriria não somente a força central, mas também saberia evitar que ela atuasse destrutivamente sobre as outras forças: antes pelo contrário, a tarefa de sua educação consistiria, como me 
parece, reconfigurar <umz ubilden> o homem para um vivamente móvel sistema de sóis e planetas e conhecer a lei de sua mecânica superior" (N IETZSCHE, 1980a p. 342).

Percebemos aqui como essa imagem do sistema de sóis e planetas, cujo vivo movimento deixa reconhecer a lei fundamental de uma mecânica superior, reencontra as metáforas anteriores do caroço aprisionado, em ânsia por germinação, e o granítico fatum espiritual de perguntas e respostas. Trata-se sempre, a meu ver, daquela concepção de formação como prática de si, como relação consigo mesmo pela mediação especular dos outros - trata-se, sobretudo, do verdadeiro educador. É da resolução de sua tarefa formadora de trato, cuidado e cultivo, que emergirão os frutos daquela semente, a lei mecânica superior daquela constelação viva.

0 grande problema, para essa teoria da educação para a autenticidade do jovem $\mathrm{N}$ ietzsche, é que faltava justamente aquele filósofo, e o que se podia apreender era, isso sim, como

"nós, homens modernos, figuramos miseravelmente em face dos gregos

e romanos, até mesmo apenas em relação ao entendimento sério e rigoroso das tarefas do ensino. Com tal necessidade no coração, pode-se atravessar toda A lemanha, principalmente todas as universidades, e não se encontrará o que se procura; e, aliás, tantos desejos muito mais baixos e mais simples permanecem aqui insatisfeitos". (N IET ZSC HE, 1980a p.343).

É por causa disso que, naquela quadra de sua vida - e, creio eu, ao longo de toda sua existência lúcida - Schopenhauer representou para $\mathrm{N}$ ietzsche o modelo do educador autêntico, como o pensador rebelde por excelência, que denunciou a vaidade oculta sob a pompa indigente das distinções acadêmicas, que obstinadamente se recusou macular a dignidade da filosofia, constrangendo-a ao convívio espúrio com a rotina universitária de funcionário público, que não se dobrou a Estado nem I greja, nem a qualquer dos outros poderes estabelecidos. Por causa disso, a virtude pedagógica e emancipatória de sua filosofia não se esgotou na estreiteza das disciplinas curriculares, nem seu exemplo de vida e pensamento gerou professores universitários e filosofia de professores, eruditos filosóficos a serviço e a soldo dos poderosos da época. 
A final, Schopenhauer também conclamava imperiosamente para uma conquista de si mesmo, por meio de sua noção de caráter adquirido:

" $\mathrm{U} \mathrm{m}$ homem tem também de saber $\mathrm{o}$ que ele quer, e saber 0 que ele pode: só assim exibirá ele caráter, e só então pode realizar algo direito. Entretanto, antes que tenha alcançado isso, e a despeito da conseqüência natural do caráter empírico, ele é todavia desprovido de caráter; e apesar de que, no conjunto, tenha de permanecer fiel a si e percorrer seu trilho, é arrastado por seus demônios, de modo que não traçará nenhuma linha reta com o fio de prumo, mas uma linha vacilante, desigual; ele hesitará, desviará, contornará, causará a si mesmo remorso e sofrimento: tudo isso porque, tanto no pequeno quanto no grande, ele vê diante de si tudo aquilo que para o homem é possível e alcançável, e todavia não sabe disso 0 que é, para ele apenas, comensurável e realizável, ou mesmo 0 que é para ele desfrutável" (SCH O PEN H AU ER , 1986, p. 418).

De acordo com a avaliação de $\mathrm{N}$ ietzsche, Schopenhauer conseguiu evitar, por seu exemplo, os dois maiores perigos da educação para a filosofia: por um lado, a rendição da cultura às potências dominantes, do Estado e do mercado, pois o "que os negociantes querem, quando exigem incessantemente educação e cultura, é sempre, no final das contas, lucro" (N IET ZSC HE, 1974, p. 84).

Por outro lado, Schopenhauer tampouco fez concessões à aridez da erudição altamente especializada. Ele não recorreu, para legitimar sua filosofia, aos modismos e jargões eruditos, pois este é o linguajar estéril dos filisteus da cultura, mas insistiu sempre no apelo à autenticidade:

"Temos que primeiro aprender pela experiência o que queremos e 0 que podemos: até lá, não o sabemos, somos sem caráter e freqüentemente temos que ser relançados em nosso próprio caminho por duros golpes exteriores. - U ma vez que o tenhamos finalmente aprendido, então conquistamos o que no mundo se chama caráter, 0 caráter adquirido. De acordo com isso, este nada mais é do que 0 conhecimento mais completo possível da própria individualidade: 0 saber abstrato e conseqüentemente claro das inalteráveis propriedades do próprio caráter empírico, assim como da medida e direção de suas próprias forças corporais e espirituais, portanto de todas as fortalezas e fraquezas da própria individualidade. 
Isso nos coloca agora em condição de conduzir refletida e metodicamente o papel, em si único e inalterável, da própria pessoa, que nós naturalizávamos anteriormente, sem qualquer regra, e de preencher as lacunas causadas pelo humor ou fraquezas, segundo a direção de conceitos firmes. 0 necessário modo de agir, de todo determinado por nossa natureza individual, nós o conduzimos agora segundo máximas claramente conscientes, permanentemente presentes, de acordo com as quais o conduzimos tão refletidamente como se fosse aprendido, sem nisso nos equivocarmos pela transitória influência do estado de ânimo ou da impressão do presente; sem ser inibidos pelo amargo ou doce das particularidades encontradas no caminho, sem calafrios, sem hesitação, sem inconseqüências" (SC H O PEN H AU ER, 1986, p. 419).

Por seu desprezo pela filosofia universitária, pseudo-erudita, Schopenhauer teria ensinado a $\mathrm{N}$ ietzsche que 0 aprendizado filosófico, descolado da vida, não pode constituir senão rotina mecânica de adestramento, pesada corvéia espiritual, nunca um caminho de efetiva elevação e construção de uma autêntica personalidade:

“E, por fim, em que neste mundo importa a nossos jovens a história da filosofia? Será que eles devem, pela confusão das opiniões, ser desencorajados de terem opiniões? Será que devem ser ensinados a participar do coro de júbilo: como chegamos tão esplendidamente longe? Será que, porventura, devem aprender a odiar ou desprezar a filosofia? Q uase se poderia pensar este último, quando se sabe como os estudantes têm que de se martirizar por causa de suas provas de filosofia, para imprimir as idéias mais malucas e mais espinhosas do espírito humano, ao lado das mais grandiosas e mais difíceis de captar, em seu pobre cérebro" (N IET ZSC HE, 1974, p. 89).

0 pensamento de Schopenhauer, como de todo verdadeiro educador, se submetia, segundo $\mathrm{N}$ ietzsche à "única crítica de uma filosofia que é possível e que além disso demonstra algo, ou seja, ensaiar se se pode viver segundo ela". U ma tal exercício crítico "nunca foi ensinado nas universidades: mas sempre a crítica de palavras com palavras" (NIETZSCHE, 1974, p. 89). 0 resultado desse exercício fútil de estéril semiformação é o 
abortamento do impulso crítico, justamente o contrário daquela tarefa da verdadeira educação para a filosofia: a frágil semente, que servia de metá fora para o processo formativo, ao invés de ganhar espaço para desabrochar, de receber luz, calor e nutrição adequada, acaba sendo barbaramente sufocada por entulhos desprovidos de espírito e interesse vital. Eis o melhor caminho para o conformismo político, para a flexível docilidade de corpos e mentes.

"E agora pense-se em uma cabeça juvenil, sem muita experiência da vida, em que cinqüenta sistemas em palavras e cinqüenta críticas desses sistemas são guardados juntos e misturados - que aridez, que selvageria, que escárnio, quando se trata de uma educação para a filosofia! M as, de fato, todos reconhecem que não se educa para ela, mas para uma prova de filosofia: cujo resultado, sabidamente e de hábito, é que quem sai dessa prova - ai, dessa provação - confessa s si mesmo com profundo suspiro: 'G raças a Deus que não sou filósofo, mas cristão e cidadão de meu estado" (N IET ZSCHE, 1974, p. 89).

É, portanto, na contramão dessas duas tentações - a de permitir que as metas fundamentais da cultura sejam determinadas por interesses al heios a ela, sejam os do Estado, ou os do mercado; e a de confundir a formação do filósofo com a do homem de ciência e do operário da filosofia - que a figura de Schopenhauer se erige como modelo de educador. M ais tarde, sem evocar expressamente a figura do antigo mestre, $\mathrm{N}$ ietzsche resume esse seu pensamento numa fórmula:

"Insisto em que finalmente cessemos de confundir os operários

filosóficos e, em geral, os homens de ciência com os filósofos, - em que precisamente aqui seja dado com rigor 'a cada um o que é seu' e àqueles não demais, a estes não de menos. Pode ser necessário, para a educação do efetivamente filósofo, que também ele uma vez tenha estado nesses níveis em que permanecem seus servidores, os operários científicos da filosofia, - em que eles têm que permanecer" (N IET ZSC HE, 1980b, p. 144s.).

O s melhores esforços da rigorosa formação erudita ascendem, todavia, a um nível limitado de formação filosófica: a dos trabalhadores científicos da filosofia. 0 ideal do verdadeiro filósofo se coloca bem mais acima 
desse alvo, pois o genuíno filósofo é o responsável pela resposta à pergunta pelo valor; é dele que brota a legislação para o dever ser do projeto humano na história:

"O s autênticos filósofos, porém, são comandantes e legisladores: eles dizem: 'assim deve ser!', eles primeiramente determinam o para onde?, o para que? do homem e, ao fazê-lo, dispõem do trabalho prévio de todos os operários filosóficos, de todos os subjugadores do passado, - eles estendem sua mão criadora para o futuro, e tudo aquilo que é e foi converteu-se para ele em meio, em instrumento, em martelo. Seu 'conhecer' é criar, seu criar é uma legislação" (N IET ZSCHE, 1980b, p. 144s.).

Para poder corresponder ao ideal do filósofo como legislador do futuro, o filósofo empírico deve satisfazer pelo menos a duas condições fundamentais. Em primeiro lugar, ele não pode instituir valores e determinar 0 que deve ser - portanto, não pode encarnar aquele a quem é legítimo dar ordens -, se primeiramente não tiver aprendido a conhecer sua própria legislação, se, enfim, não tiver descoberto a lei da mecânica superior, a partir do conhecimento do sistema de sóis e planetas, que ele é. D esse modo, só pode comandar aquele que primeiro soube obedecer à legislação de sua própria vontade, pois, para $\mathrm{N}$ ietzsche, "deve ser comandado aquele que é incapaz de obedecer a si próprio" (N IET ZSCHE, 1980e, p. 147).

"Viver com uma formidável e orgulhosa serenidade; sempre para além.

Ter e não ter, conforme sua vontade, seus afetos, seu prós e contras, condescender com eles, por horas, montarmos sobre eles, como sobre cavalos, com freqüência como sobre asnos: - é preciso saber aproveitar, com efeito, tanto a estupidez deles, como seu fogo [...] E permanecer senhor de nossas quatro virtudes: a coragem, a lucidez, a simpatia e a solidão" (N IET ZSCHE, 1980b, p. 231s.).

Senhor da lei de sua própria vontade, finalmente conquistada a duras penas, o verdadeiro filósofo e educador não pode ser o legislador para 0 futuro do homem se ele não for também o mais inflexível inimigo da autocomplacência de seu próprio hoje. $0 \mathrm{u}$, para dizê-lo num fórmula ainda mais simples: é por resistir àquelas duas maneiras eficazes de fuga de si, de autocomprometimento pessoal com a filosofia, a saber: a autodemissão da tarefa de determinar os alvos mais elevados da cultura, relegan- 
do-os ao arbítrio dos negociantes culturais; e a de deixar-se confundir com os laboriosos trabal hadores científicos especializados, que o jovem $\mathrm{N}$ ietzsche evocava o exemplo formador de Schopenhauer. M uitos anos depois, quando já se consumara a despedida de seu venerado mestre, cicatrizadas as feridas que o rompimento causara, aquilo que nele fora projetado, passa a valer para o conceito de filósofo, em geral:

"A mim quer me parecer sempre mais que o filósofo, como um necessário homem do amanhã e depois de amanhã, sempre se encontrou e teve de se encontrar em contradição com seu hoje: seu inimigo foi, a toda vez, o ideal de hoje. A té agora, todos esses extraordinários promotores do homem, que são denominados filósofos e que raramente sentem a si mesmos como amigos da verdade, porém antes como desagradáveis loucos e perigosos pontos de interrogação - , encontraram sua tarefa, sua dura, involuntária, incontornável tarefa, finalmente, porém a grandeza de sua tarefa, em ser a má consciência de seu tempo. Ao colocar justamente no busto da virtude do tempo o bisturi de vivissecção, eles delataram qual era o seu segredo: saber de uma nova grandeza do homem, um novo, não percorrido caminho para seu engrandecimento. Eles desvelaram, a cada vez, quanta hipocrisia, comodidade, deixar-se levar e deixar-se cair, quanta mentira se esconde sob o tipo mais venerado de sua moralidade contemporânea, quanta virtude foi sobrevivida, a cada vez, eles disseram: 'temos que ir para lá, para fora, onde vós hoje menos vos sentis em vossa casa" (N IET ZSC HE, 1980b, p. 145s.).

E aqui podemos encontrar, para nosso espanto, a oportunidade adequada para um paralelo com o exemplo de Kant - do filósofo que $\mathrm{N}$ ietzsche injustamente considerava um antípoda de Schopenhauer, e a quem alcunhou 0 "chinês de K önigsberg", numa referência a seu talento inexcedível para operário da filosofia. É muito curioso observar o paralelismo e a parcial coincidência de imagens e posições.

Para K ant, como sabemos, a filosofia, tomada em seu pleno conceito é apenas um ideal para figurar a totalidade do conhecimento filosófico, a saber o sistema completo da ciência possível. Essa totalidade completa, por não encontrar nenhum correspondente na realidade empírica, não pode, portanto, ser ensinada. É isso que podemos ler no terceiro capítulo 
da doutrina transcendental do método, dedicado por Kant, na primeira C rítica, à arquitetônica da razão pura; aí encontramos a seguinte definição lapidar de filosofia:

"A Filosofia é, pois, o sistema de todo o conhecimento filosófico. É necessário tomá-la objetivamente caso se compreenda por Filosofia o arquétipo para se julgar todas as tentativas de filosofar; este arquétipo deve servir para julgar toda a filosofia subjetiva, cujo edifício é freqüentemente tão diversificado e tão mutável. D este modo, a filosofia é uma simples idéia de uma ciência possível que não é dada em parte al guma; seguindo diversos caminhos, procuramos avizinhar-nos desta idéia até descobrirmos a única senda, bastante obstruída pela sensibilidade, e conseguirmos igualar ao arquétipo, tanto quanto seja dado a seres humanos, a cópia até então defeituosa" (KAN T, 1980, p. 407; B 866; tradução ligeiramente modificada).

$\mathrm{N}$ ão encontramos realizada, na experiência, essa idéia de um sistema completo dos conhecimentos filosóficos. Tudo que podemos fazer é nos aproximar dela, percorrendo o caminho proposto pelo programa crítico kantiano e nos esforçando para completar, até onde isso é possível para os esforços humanos, uma arquitetônica geral da razão humana: essa é a "única senda, bastante obstruída pela sensibilidade", de que tratava o texto acima citado. Justamente porque 0 sistema dessa ciência constitui uma realidade apenas ideal, não podemos ensinar nem aprender filosofia.Tudo 0 que podemos fazer é aprender a filosofar, a partir de um exerácio realiz ado com as tentativas históricas de filosofar, ou seja, com a história da filosofia.

"A té então, não se pode aprender qualquer filosofia; pois onde esta se encontra, quem a possui e segundo quais características se pode reconhecê-la? Só é possível aprender a filosofar, ou seja, exercitar o talento da razão, fazendo- 0 seguir os seus princípios universais em certas tentativas existentes, mas sempre reservando à razão o direito de investigar aqueles princípios até mesmo em suas fontes, confirmandoos ou rejeitando- os" (KAN T, 1980, p. 407s; B 866).

$M$ as, além desse conceito escolar, ou escolástico, de filosofia como unidade sistemática e perfeição lógica do conjunto do conhecimento possível, existe, para Kant, 
"um conceito cósmico (conceptus cosmicus), que sempre foi tomado como o fundamento do termo filosofia, principalmente quando por assim dizer se o personificou e se o representou como um arquétipo ideal do filósofo. N este sentido, a Filosofia é a ciência da referência de todo o conhecimento aos fins essenciais da razão humana (teleologia rationis humanae), e 0 filósofo é não um artista da razão, mas sim 0 legislador da razão humana." (KAN T, 1980, p. 408; B 866-867).

E aqui podemos fazer comungar os esforços de K ant e de $\mathrm{N}$ ietzsche para exorcizar os dois grandes perigos que rondam a formação do filósofo: 0 perigo da submissão a fins alheios e o perigo da especialização esterilizante. Pois, de acordo com o kantiano conceito cósmico de filosofia, esta significa a "referência de todo o conhecimento aos fins essenciais da razão humana", fins esses que são de natureza ética e dos quais o filósofo (e ninguém mais) constitui o legítimo gestor. Logo, toda e qualquer esfera da cultura superior deve estar referida, segundo esse conceito, aos fins essenciais da razão, aos quais deve se submeter. Portanto, não se pode prescrever de fora fins alheios e heterônomos para a verdadeira filosofia.

$R$ epresentando um modelo pessoal do arquétipo da filosofia, o filósofo é, também para Kant, legislador. Ele não é, portanto, artista (na linguagem de $\mathrm{K}$ ant), ou operário científico (no léxico de $\mathrm{N}$ ietzsche), mas legislador da razão humana:

"O matemático, o estudioso da natureza e o lógico, por mais notável que seja o progresso dos primeiros no conhecimento racional e o dos segundos, particularmente no conhecimento filosófico, não passam de artistas da razão. $\mathrm{N} o$ ideal ainda existe um mestre que a todos impõe a sua tarefa e os utiliza como instrumentos para promover os fins essenciais da razão humana. É somente a este que devemos denominar filósofo" (KANT, 1980, p. 408; B 867).

Permanecendo no plano ideal, temos que reconhecer que, de um ponto de vista sistemático, completo e perfeito, os fins essenciais da razão não podem ser ainda os fins supremos; pois só pode haver um único fim supremo, quando se atinge ou representa uma perfeita unidade sistemática da razão. " $C$ onseqüentemente, os fins essenciais são ou o fim último ou fins subalternos que como meios pertencem necessariamente àquele. 0 
fim último não é outro senão a inteira destinação do homem, e a filosofia a respeito dessa última chama-se M oral" (KAN T, 1980, p. 408; B 868).

Filosofia adquire, nessa acepção, o sentido de legislação da raz ão humana, e o filósofo é, portanto, aquele que pode ser denominado, em sentido pleno, o legislador e gestor do fim supremo da razão: aquele que deve assumir a responsabilidade pela destinação do homem como ser moral. Portanto, constitui assomo de arrogância sequer pretender estar à altura de tão sublime missão. "N este significado, seria assaz vanglorioso chamarse a si mesmo de filósofo e arrogar-se uma identidade com 0 arquétipo existente unicamente na idéia".

Eis porque a dignidade filosófica só pode ser conferida, na realidade empírica, por analogia; sendo assim, a mera "aparência externa de um autodomínio [adquirido] mediante a razão faz com que ainda hoje, segundo uma certa analogia, denominemos alguém de filósofo, por mais limitado que possa ser o seu saber" (KANT, 1980, p. 408; B 868). Se a filosofia é a legislação que institui o fim supremo da razão humana, então o filósofo é, essencialmente, educador. Pois, de acordo com a pedagogia filosófica de Kant, educar significa o esforço solidário de gerações humanas, pelo qual o indivíduo é elevado ao nível do desenvolvimento coletivo do gênero humano, de modo a poder integrar, como membro pleno, a sociedade cosmopolita dos seres racionais, com pleno acesso e disposição sobre o patrimônio cultural da espécie humana.

$\mathrm{N}$ o plano mais amplo do gênero humano, educar significa desenvolver cada vez mais as disposições naturais para a H umanidade, um processo indefinidamente em aberto, conduzindo o homem progressivamente para um ideal de perfeição que corresponda à idéia de humanidade. Educar, portanto, é uma tarefa eminentemente ética, que não se confunde com o adestramento para obter sucesso no presente, mas formar e elevar 0 homem ao nível de plenitude figurado nesse ideal. A esse processo indefinidamente aberto sobre o futuro - corresponde o conceito tipica mente kantiano de educação, formulado, entre outros lugares, em seus escritos pedagógicos.

Estou plenamente ciente das diferenças incontornáveis entre os modelos teóricos de $\mathrm{K}$ ant e de $\mathrm{N}$ ietzsche, tanto aquelas que dizem respeito às inspirações fundamentais, quando as de conteúdo e de forma. Todavia, ao aproximá-los, meu propósito foi refletir sobre aos perigos que 
ainda nos assediam hoje, e que o ideal de educação para a filosofia, por eles esboçado, talvez nos ajude a conjurar.

R efiro-me, primeiramente, ao risco envolvido na especialização extrema e atomizante, a que pode conduzir uma erudição meramente histórico-filológica, desacompanhada de motivação e interesse vital; um risco, aliás, firmemente fomentado pela racionalização utilitarista e pela moderna divisão mercantil da produção intelectual. R efiro-me, em associação com isso, ao perigo de submeter o ideal de formação a injunções e interesses que lhe são estranhos e que podem conduzir ao barateamento irreversível do talento filosófico. É por isso que devemos estar atentos ao que nos apregoam como "flexibilização", adaptação às necessidades regionais ou mercadológica.

$R$ efiro-me também à urgência e à necessidade de fazer com que 0 estudo rigoroso e especializado da história filosofia não se esgote na minuciosa ourivesaria conceitual das opiniões alheias, que se obstina em inibir a coragem e 0 impulso para as opiniões próprias. R efiro-me, por fim, a essa perigosa autodemissão da filosofia de sua condição de gestora do fim supremo da razão.

$\mathrm{N}$ um tempo em que se encontra gravemente ameaçada a base somática da personalidade moral, numa época em que se anuncia - com todo rumor do sensacionalismo midiático - a reduplicação tecnológica de seres humanos e a produção mercantil desse "material" de acordo com as demandas do mercado, seria indispensável retornarmos aos antigos arquivos onde ficaram conservadas as inspirações ideais de nosso esforço de formação para a filosofia.

1 “ $M$ as como nos encontramos novamente a nós mesmos? C omo o homem pode conhecer a si mesmo? Ele é uma coisa escura encoberta; e se o coelho tem sete peles, então o homem pode extraí- las sete vezes setenta vezes, e todavia não poderá dizer: 'agora és tu efetivamente, isso não é mais casca'. A lém disso, é um penoso, perigoso começo escavar de tal modo em si próprio, e precipitar-se violentamente, pelo caminho mais próximo, no tesouro de sua essência. Q uão facilmente lesa- se ele com isso, de tal modo que nenhum médico pode curá lo. $E$, além disso, para que isso seria necessário, se, com efeito, tudo presta testemunho de nossa essência, nossas amizades e inimizades, nosso olhar e nosso aperto de mão, nossa memória e aquilo que esquecemos, nossos livros e os traços de nosso punho. Porém, para prestar ouvidos ao mais importante, há o seguinte meio. Q ue a jovem alma lance seu olhar retrospectivamente 
sobre a vida, com a pergunta: o que, até agora, verdadeiramente amaste, o que atraiu a tua alma, o que a dominou e, ao mesmo tempo, a felicitou? Coloca diante de ti a série desses venerados objetos, e talvez, por sua essência e sucessão, eles te proporcionem uma lei, a lei fundamental do teu autêntico si próprio. Compara esses objetos, vê como um complementa, alarga, sobrepuja, transfigura o outro, como eles formam uma escada, sobre a qual até agora te elevaste para ti mesmo; pois a tua verdadeira essência não jaz profundamente oculta em ti, mas imensamente acima de ti, ou ao menos sobre aquilo que habitualmente tomas como o teu eu. Teus verdadeiros educadores e formadores te revelam o que é o verdadeiro sentido originário (U rsinn) e a matéria fundamental (Grundstoff) de tua essência, algo inteiramente impermeável ao ensino e à figuração, mas em todo caso dificilmente acesśvel, preso, entravado: teus educadores conseguem não ser senão os teus libertadores. $E$ este é o segredo de toda formação: ela não proporciona próteses artificiais, narizes de cera, olhos lentificados - pelo contrário, é apenas imitação de educação aquilo que conseguiria dar tais prendas. Esta, porém, é libertação, remoção de toda erva daninha, entulho, vermes que querem atingir a delicada semente da planta, jorro de luz e calor, amoroso murmúrio de chuva noturna; ela é imitação e adoração da natureza, onde esta é maternal e misericordiosamente disposta; é aperfeiçoamento da natureza, quando previne e volta para o bem os cruéis e impiedosos ataques da natureza, quando estende um véu sobre as manifestações de sua disposição madrasta e de sua triste incompreensão." (N IET Z SC HE, 1980a, p. 340s.).

\section{Referências bibliográficas}

KAN T, I. 1980. C rítica da R azão Pura. Tradução:Valério R ohden e U do Baldur M oosburger. C oleção 0 s P ensadores, São Paulo: A bril Cultural.

N IET ZSC HE, F. 1980a. Terceira C onsideração Extemporânea. Schopenhauer como E ducador. In: SämtlicheW erke (K ritische Studienausgabe, abreviada como KSA). Ed. G. Colli e M . M ontinari. Berlin, N ew York, M ünchen: de Gruyter, DTV. 1980, vol. 1. N ão havendo indicação em contrário, as traduções são de minha autoria.

N IETZSCHE, F. 1980b. Para A lém de B em e M al. In: KSA, op. cit.Vol. 5.

N IET ZSC HE, F. 1980c. D a Vantagem e D esvantagem da H istória para a Vida. In: KSA, op. cit.Vol. 1.

N IET ZSC HE, F. 1974. 0 bras Incompletas. Tradução: R ubens R odrigues Torres Filho. Coleção 0 s Pensadores, 1 ạ ed. São Paulo:A bril C ultural.

N IET ZSC HE, F. 1980d. A ssim F alou Z aratustra, II. D a Superação de Si. In: KSA, op. cit.Vol. 4. 
96

SCH O PEN H AU ER , A. 1986. D ieW elt alsW ille und V orstellung (0

$M$ undo como V ontade e R epresentação). in: SämtlicheW erke. Ed. Wolfgang

Frhr. von Löhneysen. Frankfurt/ M : Suhrkamp, vol. 1.

doispontos, Curitiba, São Carlos, vol. 2, n. 2, p.77-96, outubro, 2005 